\title{
Correlation Study of Motivation and Habits to Learn Japanese Language With Result of Japanese Language Proficiency Test
}

\author{
Rosi Rosiah $^{1, *}$ Azizia Freda Savana ${ }^{2}$, Rati Narendra Warisman ${ }^{3}$ \\ ${ }^{1}$ Universitas Muhammadiyah Yogyakarta \\ ${ }^{2}$ Universitas Muhammadiyah Yogyakarta \\ *Email: rosi.rosiah@umy.ac.id
}

\begin{abstract}
The study is interested in finding a correlation between motivation and study habits with Japanese Language Proficiency Test N3. Students of the Japanese Language Study Program at Universitas Muhammadiyah Yogyakarta 4th Grade the academic year 2018-2019. This research used a quantitative approach with a correlational approach. The research variables were Motivation (X1), study habits (X2), and the results of JLPT N3 (Y). The sample was 20 students determined by the non-probability sampling technique. Data were collected using questionnaires and document analysis. The questionnaire assessed motivation and study habits and documents to determine the Japanese Language Proficiency Test N3. Data analysis used multiple correlation analysis with the help of SPSS Statistics version 23. In the final results of calculations with various correlation analyses, Ha was rejected. There was no correlation between Motivation (X1) and study habits (X2) with Japanese Language Proficiency Test N3 (Y) in 4thgrade students of Japanese Language Department UMY, 2018-2019. The known F value is $0.543<$ FTabel 3.55, and the sig F Change value was $0.591>0.05$. The hypothesis received in this study is that there is no correlation between motivation and study habits with the Japanese Language Proficiency Test N3.
\end{abstract}

Keywords: Correlation, Motivation, Study Habits, Japanese Language Proficiency Test

\section{INTRODUCTION}

The progress of education in a nation can be a benchmark for the development of the nation. Through education, the young generation is expected to become a quality generation. Education is a conscious effort done deliberately in which its influence can nurture the maturity of students so that they can develop their potential as provisions for life in society [1].

Motivation is an encouragement to do something to achieve goals. In achieving the desired goal, a person needs encouragement or motivation, both motivation that comes from within oneself and motivation that comes from outside. According to Suryabrata (2006: 70 ), motivation is a state that exists in a person that encourages him to carry out certain activities to achieve a goal. Meanwhile, motivation as a physiological and psychological condition in a person that regulates his actions in specific ways [2]. Motivation is generating, directing, and strengthening behavior towards a goal [3].
Once the importance of students' motivation in supporting learning success, it would be nice for them to generate learning motivation for their students.

\subsection{Kinds of Motivation}

Types of learning motivation, according to [1].

1. Motivation that is seen from the basis of its formation, namely innate motives, means motives carried from birth. This motive exists without having to be biologically studied and required. Meanwhile, the studied motives are those that exist because they are studied and socially required. After all, humans are social creatures who must interact with other humans to form this motif.

2. Motivation, according to the division of Woodworth and Marquis, consists of organic motives, namely basic human needs, such as eating, drinking, resting, and others. An emergency motive in the form of encouragement to save student self, retaliate, try chase, Etc. Meanwhile, the objective motive is the need to explore, manipulate, take interest, and others. 
3. Physical and spiritual Motivation. Physical motivation is in the form of reflexes, automatic instincts, and lust. Meanwhile, spiritual motivation is in the form of willingness.

4. Intrinsic and Extrinsic motivation. Intrinsic motivation means a motive that becomes active or will function by itself without needing to be stimulated from the outside. Extrinsic motivation means a motive that will function in the presence of external stimuli.

To achieve a better quality of education, motivation, and learning habits of students are needed. Mc. Donald defines motivation as a change of energy in a person characterized by the emergence of affective (feelings) and reactions to achieve goals [4]. Motivation has several types, one of which is intrinsic Motivation and Extrinsic Motivation [5]. Besides motivation, other factors that influence learning are study habits [6].

Learning habits will affect learning to gain knowledge, attitudes, skills, and skills, making schedules and implementation, reading and taking notes, repeating lesson material, concentrating, and working on assignments [7].

Learning habits are learning activities that are carried out continuously or repeatedly with the same method to increase knowledge of the subject matter. Habits are generally carried out without realizing it by the individual who owns them. In the Big Indonesian Dictionary, habits can be defined as patterns for responding to specific situations learned by an individual and which he repeatedly does for the same thing.

According to Burghardt, quoted by Shah (2006) in his book Learning Psychology states that [8].

"The learning habit arises because of the process of shrinking the response tendency by using repeated stimulation. The learning process carried out by a person, and habituation also includes reducing unnecessary behavior. This process of shrinking or reducing emerges a new pattern of behavior that is relatively permanent and automatic.

Study habits are formed because they are repeated throughout an individual's life and usually follow a certain way or pattern to form learning habits [9].

Learning aims to make changes within, including behavior (changes in behavior), changing habits (from bad to good), changing attitudes (from negative to positive), changing skills, increasing knowledge in various fields of science. By learning to improve fate, achieve the desired goals [10].

Every student who has experienced the learning process, his habits will appear to change [8]. For example, students who learn language repeatedly will avoid using words or structures that are wrong and eventually get used to using the language correctly. So speaking correctly and correctly is a manifestation of student learning behavior, which will eventually become a habit.

Learning is a business process carried out by a person to obtain a whole new change in behavior due to his own experience in interaction with his environment [7]. Every change in a person cannot be said to be the result of the learning process; there are characteristics of behavior changes, among others.

1. Change occurs consciously

2. Changes in learning are continuous and functional

3. Changes in learning are lively and active

4. Changes in learning are not temporary

5. Changes in learning are purposeful or directed

6. Change covers all aspects of behavior

Another opinion was conveyed by Djali (2018). argues that study habits can be interpreted as methods or techniques that settle in students when receiving lessons, reading books, doing assignments, and setting time to adjust activities [6]. He also states in his book that learning habits are divided into two parts, namely [6]:

1. Delay Avoidance (DA) refers to timeliness in completing academic tasks, avoiding things that allow delays in completing tasks, and eliminating stimuli that will interfere with learning concentration.

2. Work Methods (WM) refers to using effective and efficient learning methods or procedures in doing academic tasks and learning skills.

\subsection{Aspects of Learning Habits}

Basically, in the learning habits carried out by all students, there are learning activities in it. There are several learning activities carried out by students, including [5]:

1. Listening is one of the activities carried out by every student in the learning process. When teachers use the lecture method, students are required to listen well to what the teacher says.

2. Viewing is one of the learning activities, but not all viewing activities can be learning.

3. Touching, smelling, and tasting or tasting are activities carried out by the human senses, which can provide an opportunity for a person to learn but must be accompanied by a purpose. Therefore, this activity can be said to be learning if it is motivated by need, motivation to achieve a specific goal with a behavior change. 
4. Writing or taking notes is an activity that is often done in learning. Writing or taking notes, which is learning, is taking notes that can support learning goals, not just taking notes.

5. Reading is an activity that is mostly done during learning. This activity can be a path to science.

These learning activities will determine the learning success of students. There are two kinds of study habits, namely good study habits that can help master lessons, achieve learning progress and achieve success, and bad study habits that make it challenging to understand knowledge, hinder progress and become failures [9].

Good study habits, according to The Liang Gie [9]:

1. Do regular study every day.

2. Prepare all study needs the night before leaving the next day.

3. Always attend the class before lessons begin.

4. Being accustomed to learning until understand very well and even entirely is unforgettable.

5. Accustomed to visiting the library to add a reading or looking at reference books to look for terms' meanings.

Bad study habits, according to The Liang Gie [9]:

1. do study furiously after exams a.

2. Just before leaving, there was much noise collecting books and equipment that needed to be brought.

3. Often late in attending.

4. Generally, learning is necessary so that the grains of knowledge are still obscure, and many are forgotten.

5. Student Rarely enters the library and does not know how to use encyclopedias and various other reference works.

These two factors (Motivation and study habits) have an essential role in increasing or decreasing learning achievement.

JLPT (Japanese Language Proficiency Test) is a language ability test used to measure Japanese language competence. This exam is held twice a year, namely in July and December. There are five levels on this exam, namely $\mathrm{N} 5$ to $\mathrm{N} 1$. Based on information from The Japanese-Language Proficiency Test Test Guide (2018), there are three assessment sections in the JLPT. The score for each section is $0-60$ points.

Universitas Muhammadiyah Yogyakarta (UMY) is one of the universities in Yogyakarta that has a Japanese Language Study Program (Pendidikan Bahasa Jepang/PBJ Study Program) to pursue an advanced education (S1). PBJ Study Program UMY also refers to the JLPT N3 equivalent as a target of achieving or qualifying graduates. On average, Japanese companies provide JLPT N3 or more applicants' qualifications because they are more fluent in speaking Japanese.

Previous research on Nihongo Noryoku Shiken by Lindafari (2018), "The Influence of Interest in Reading Japanese Texts on Nihongo Noryoku Shiken N3 Results", found that interest in reading Japanese texts did not significantly influence the students' dokkai at Universitas Muhammadiyah Yogyakarta [11]. The result of the simple regression calculation was $t$ count $1.607<\mathrm{t}$ table 2.048. The significance value was 0.119 , and $\mathrm{R}$ Square's value was $8.4 \%$ with a regression equation $\mathrm{Y}=9.078+0.222 \mathrm{X}$. The difference between this study and Lindafari (2018)'s study is variable and subjek of study. Lindafari (2018) study talk about the influence of interest in reading Japanese text and result of reading competence of JLPT. In the Japanese study is rare to study about correlation and study habits.

Another previous research is the relationship between study habits and learning motivation with the science learning outcomes of Grade VII students of SMP Negeri 1 Ciseeng. This study showed that Study habits and learning motivation collectively have a positive and significant relationship in study science. This result is shown by the value of the correlation coefficient between $\mathrm{X} 1, \mathrm{X} 2$, and $\mathrm{Y}$ is 0.885 , and the coefficient of determination equal to $78.3 \%$, which means that it has a healthy relationship. From the results of the regression analysis, it can be seen that the $F$ value count the habit learning and learning motivation together on science learning outcomes amounting to 66,842 with a significance value equal to 0,000 and the value of $\mathrm{F}$ table with $\mathrm{N}=40$ and a significance of 0.05 was obtained amounting to 3.255 . Because the value of $\mathrm{F}$ count $66,842>\mathrm{F}$ table 3.255 and significance $<0.05$, then $\mathrm{H} 0$ is rejected, and $\mathrm{H} 1$ is accepted. Thus, it can be concluded that there is a relationship between study habits and motivation to learn together with learning science [12]. This study is in science learning but in language learning is still rare.

Another research is that the Japanese Language Education department can facilitate students' goals to improve their communication skills by increasing student opportunities to communicate in Japanese, for example, by optimizing Kaiwa lectures and optimizing student association programs [13]. Motivation in this study is motivation to choose Japanese language study Department as a majors in university. In this study show that student first motivation is to improve their communication skills. One to indicate the communication skills is with follow JLPT. But, in the fact that is Japanese Languagae Education Program is difficult to pass the exam of JLPT. To find the answer this study is try to find correlation between motivation 
and study habits. There must be a relationship between motivation and study habits in result of JLPT.

In contrast to previous research on the results of JLPT N3 influenced by the interest in reading Japanese texts, the researcher wants to examine the factors that correlate with the results of JLPT N3. The researchers are interested in investigating whether motivation and learning habits have a relationship with the results of JLPT N3. This study aims to

1. How is the motivation of level IV students of the UMY PBJ Study Program for the 2018-2019 academic year?

2. What are the study habits of level IV students of the UMY PBJ Study Program for the 2018-2019 academic year?

3. Is there a relationship between learning motivation and study habits with the results of the JLPT N3 level IV students of the UMY PBJ Study Program for the 2018-2019 academic year?

\section{RESEARCH METHODS}

Correlational methods will be used in this study to determine whether motivation and study habits correlate with the Japanese Language Proficiency Test N3.

The data collection method in this study used questionnaires and document analyses. The questionnaire was in the -form of close-ended questions rated using a Likert scale validated by experts. The analyzed documents were in the form of the results of the Japanese Language Proficiency Test N3. This study Sample is 4th-grade students of the Japanese Language Department Universitas Muhammadiyah Yogyakarta for the 2018-2019 academic year who had participated in Japanese Language Proficiency Test N3.

The questionnaire was for validity and reliability by calculating Product Moment correlation and Cronbach's Alpha using SPSS Statistics version 23. The validity of the questionnaire result shows that all questions in the questionnaire are valid. Moreover, the reliability of the questionnaire The reliability test used Cronbach's Alpha with the application of SPSS Statistics version 23. The questionnaire instrument was said to be reliable if the Cronbach Alpha value was> 0.6. Moreover, the result shows that the questionnaire is reliable. This study Is a correlation study and Data analysis using product moment. Used to see the direction of the correlation between the independent variable and the dependent variable (bivariate), whether it is positive or negative for variable $\mathrm{X} 1$ to variable $\mathrm{Y}$ and variable $\mathrm{X} 2$ to variable $\mathrm{Y}$ so that the direction of the relationship can be seen.
The hypotheses in this study are:

Ha: There is a correlation between motivation and study habits with JLPT N3 in the fourth-year students of PBJ Study Program UMY in the academic year 2018 - 2019.

H0: There is no correlation between motivation and study habits with JLPT N3 in the fourth-year students of PBJ Study Program UMY in the academic year 2018 2019.

The hypothesis is accepted if: $\mathrm{H} \_\mathrm{a}$ is accepted, and H_O is rejected if $r_{-}$count is higher than $r$ _tabel (r_count> r_tabel). Data analysis used multiple correlation analysis with the help of SPSS Statistics version 23 .

\section{FINDING AND DISCUSSION}

Before a multiple correlation analysis, several steps must be performed, including:

\subsection{Scoring}

Rating gives a score or a value on the questionnaire answers collected.

\subsection{Descriptive Analysis of the Questionnaire}

Based on the motivation questionnaire description, a maximum value of 50 was obtained; a minimum of 28 ; a mean of 39.30; the standard deviation of 5.94. The data are then divided into three categories: high, medium, and low. After being processed using the formula in Table 1.1 above, three respondents have a high motivation (15\%), 16 respondents have the moderate motivation (80\%), and one respondent has low motivation $(5 \%)$. Thus, the motivation of level IV students of the PBJ Study Program UMY falls into the medium category. This finding is different from previous research conducted in Lindafari's previous research (2018) found that the Motivation of Japanese language learners in the Japanese Language Education Study Program is high, but in this study's findings, the motivation of medium or middle students.

In the study habits questionnaire, based on the study habits questionnaire's description, a maximum value of 35 was obtained; a minimum of 14 ; mean of 23.10; the standard deviation of 5.84, then categorized into three categories, namely high, medium and low. After the value is processed using the formula in Table 1.1, four respondents have high learning habits $(20 \%)$, moderate learning habits in 13 respondents $(65 \%)$, and three respondents have low learning habits $(15 \%)$. Based on the results obtained, fourth-level PBJ Study Program students, UMY's learning habits, go into the medium. 
According to Burghardt, in his book Learning Psychology states that: "The learning habit arises because of the process of shrinking the response tendency by using repeated stimulation [8]. A person carries out the learning process; habituation also includes reducing unnecessary behavior. This process of shrinking or reducing emerges a new pattern of behavior that is relatively permanent and automatic. Learning habits are formed because they are repeated throughout an individual's life and usually follow a certain way or pattern to form learning habits [9]. Learning aims to make changes within, including behavior (changes in behavior), changing habits (from bad to good), changing attitudes (from negative to positive), changing skills, increasing knowledge in various fields of science [10]. By learning to improve fate, achieve the desired goals. Every student who has experienced the learning process, his habits will appear to change [8]. For example, students who learn language repeatedly will avoid using words or structures that are wrong and eventually get used to using the language correctly. So speaking correctly and correctly is a manifestation of student learning behavior, which will eventually become a habit. Learning is a business process carried out by a person to obtain a whole new change in behavior due to his own experience in interaction with his environment [7. Every change in a person cannot be said to be the result of the learning process; there are characteristics of behavior changes, among others. a. Change occurs consciously b. Changes in learning are continuous and functional c. Changes in learning are lively and active d. Changes in learning are not temporary e. Changes in learning are purposeful or directed $\mathrm{f}$. The change covers all aspects of behavior. Another opinion was conveyed by [6]. argues that study habits can be interpreted as methods or techniques that settle in students when receiving lessons, reading books, doing assignments, and setting time to adjust activities. Learning habits are divided into two parts, namely: a. Delay Avoidance (DA) refers to timeliness in completing academic tasks, avoiding things that allow delays in completing tasks, and eliminating stimuli that will interfere with a concentration in learning [6]. b. Work Methods (WM) refers to using effective and efficient learning methods or procedures in doing academic tasks and learning skills.

The last is the result of Japanese Language Proficiency Test N3. Description of results of Japanese Language Proficiency Test N3 obtained a maximum value of 115 ; a minimum of 47 ; mean of 77.90 ; the standard deviation of 20.9. After that, it is categorized into three categories, namely high, medium, and low. Based on calculations done using the formula in Table 1.1, six respondents have a high total score $(30 \%)$, with an average total score of 10 respondents $(50 \%)$, and four respondents have a low total score (20\%). Thus, the total score of Japanese Language Proficiency Test N3 level IV students of the Japanese Language Education Department goes into the medium category.

\subsection{Correlation Hypothesis Test}

This test is to see a correlation between the independent variables partially or simultaneously with the dependent variable. After all the classical assumption test requirements, a final analysis is performed to determine whether the variables $\mathrm{X} 1$ and $\mathrm{X} 2$ correlate with the $\mathrm{Y}$ variable by conducting a correlation analysis.

\subsubsection{Product Moment Correlation Analysis}

After partial Product Moment correlation analysis, the motivation variable's significance value $(\mathrm{X} 1)$ is $0.401>0.05$. The significance value of the learning habits variable $(\mathrm{X} 2)$ is $0.859>0.05$, so between the motivation variable (X1) and results from JLPT N3 (Y), there is no relationship. Likewise, the study habits variable (X2) with the JLPT N3 (Y) outcome variable have no relationship.

The correlation value on the motivation variable (X1) -0.199 can be interpreted as the relationship between the two variables $\mathrm{X} 1$ and $\mathrm{Y}$ is a non-directional relationship. However, the learning habits variable shows a positive correlation value of 0.042 , so that the relationship between variable $\mathrm{X} 2$ and $\mathrm{Y}$ is a direct relationship.

\subsubsection{Multiple Correlation Analysis}

Multiple correlations are to determine the correlation between the independent variables of Motivation (X1) and study habits (X2) simultaneously with the dependent variable results from JLPT N3 (Y).

Sig value The F Change in Table 1.7 is $0.591>0.05$, so that the motivation variable (X1) and the study habits variable (X2) with the JLPT N3 (Y) outcome variable are uncorrelated.

According to the data results, moderate motivation, moderate study habits, and moderate JLPT N3 result resulted in no correlation between the three variables. This result is different from previous research conducted by Lindafari and Achyanadia, which stated a correlation between motivation and learning habits among students. It can also be concluded that the objects drawn are different and thus affect the results. For example, in Lindafari's research, the object is the Reading section only, and in Achyanadia's research, the science subject is the object of research. JLPT N3 is difficult to obtain if a student does not have the right motivation and study 
habits. To get the maximum JLPT N3 score, students must increase their motivation and change their study habits.

This Research Finding is different from the research conducted by The majority of Gardner's studies on motivation were concerned with finding correlations between high scores on the $\mathrm{AA}\{\mathrm{TB}$ and high levels of proficiency. Many of these studies showed that integratively motivated students, regardless of language aptitude, were more likely to acquire a second language than those less motivated. Such students tended to stay with their language programs longer. However, as $\mathrm{Au}$ (1988) pointed out, several studies have also revealed zero or antagonistic relationships between scores on the A/MTB and proficiency.

Three articles examined the relationships between motivation and students' classroom characteristics. Gliksman, Gardner, and Smythe (1982) focused on whether integratively motivated students had greater classroom participation levels, produced better quality responses, and had more positive attitudes toward the class. Berwick and Ross (1989) looked at motivation and proficiency in a Japanese context and attempted to describe variables that may affect changing motivation over time. Ely (1986) showed.

\section{CONCLUSION}

From the questionnaire distributed to students, the results of motivation, study habits, and JLPT N3 results are in the medium category, namely $80 \%, 65 \%$, and $50 \%$. The hypothesis received in this study is that there is no correlation between motivation and study habits with the results from JLPT N3 (Ha is rejected, and H0 is accepted). That show that There is no correlation between motivation and study habits with JLPT N3 in the fourth-year students of PBJ Study Program UMY in the academic year 2018 - 2019.

As studies that discuss the correlation between motivation and learning habits with the results of JLPT $\mathrm{N} 3$ are still rare, this study is the first study regarding the correlation of motivation and learning habits with outside factors of learning itself. The next researcher should examine any factors other than motivation and study habits that correlate with the results of JLPT N3.

\section{REFERENCES}

[1] Rahmat, and Pupu Saeful. Psikologi Pendidikan. Jakarta: Bumi Aksara, 2018

[2] Gates, J Arthur. Educational Psycology. New York: The MacMillan Company, 1954.

[3] Greenberg, Jerald. Managing Behavior in Organization. New York: The MacMillan Company, 1996

[4] Djamarah, Saiful Bahri. Psikologi Belajar. Jakarta: Rineka Cipta, 2015.

[5] Wahab, Rohmalia. Psikologi Belajar. Jakarta: Rajawali Pers, 2016.

[6] Djali. Psikologi Penelitian. Jakarta: Bumi Aksara, 2018.

[7] Slameto. Belajar dan Faktor-Faktor Yang Mempengaharui. Jakarta: Rineka Cipta, 2010.

[8] Syah, Muhibin. Psikologi Pendidikan Dengan Pendekatan baru. Bandung: PT Remaja Rosdakarya, 2006.

[9] Rohman, Abdul. "Hubungan Kebiasaan Belajar Dengan Prestasi Belajar Siswa Kelas IV SD Pada Mata Pelajaran Matematika di Gugus V Kecamatan Wonosari Kabupaten Gunung Kidul Tahun Ajaran 2011/2012." 2012. https://esprints.uny.ac.id.9036 (accessed 07 20, 2019).

[10] Dalyono. Psikologi Pendidikan. Jakarta: Rineka Cipta, 2007.

[11] Lindafari, Rikanita. "Pengaruh Minat Baca-Teks Bahasa Jepang Terhadap Hasil JLPT N3." repository. 2018. http://repository.umy.ac.id (accessed 09 25, 2018).

[12] Achyanadia, S. (2013). HUBUNGAN KEBIASAAN BELAJAR DAN MOTIVASI BELAJAR DENGAN HASIL BELAJAR IPA SISWA KELAS VII SMP

[13] Suryadi, D., \& Rosiah, R. (2018). Motivasi Belajar Bahasa Jepang Mahasiswa Program Studi Pendidikan Bahasa Jepang Universitas Muhammadiyah Yogyakarta. Journal of Japanese Language Education and Linguistics, 2(1), 168181. https://doi.org/10.18196/jjlel.2110 